\title{
Political Geography of the South: \\ A Spatial Analysis of the 2008 Presidential Election
}

\section{Chad J. Kinsella}

The region identified as the "South" arguably has been and continues to be the most politically interesting and analyzed region in the United States. Using election results and county maps of the eleven southern states, this study provides a spatial analysis of the counties in this region. Through the use of Geographic Information Systems (GIS), this study analyzes the 2008 presidential election using counties as the unit of analysis within these states. This exploratory study will provide data as to which candidate won each county as well as a "landslide" county map that denotes counties that supported a candidate by a margin of twenty percent or more. This study will also investigate the difference in county-level voting between the 2004 and 2008 election to see how the preferences of the electorates changed. Finally, a contextual analysis, using data gathered from the United States Census Bureau will identify county population demographics that help explain voting behavior as well as the change in vote between 2004 and 2008.

The unique American region referred to as "The South" is arguably the most politically interesting and most heavily studied of all regions within the United States. Its unique history and culture has yielded extensive attention from political scientists. Current population trends that continue to favor the region have led to increased attention from pundits, politicians, and scholars alike. Given the significant demographic changes and added electoral importance of southern states, a spatial analysis of the voting behavior in the region is warranted. The 2008 presidential election represents an interesting time, politically, for southern states replete with many changes and, conversely, much remaining the same.

For this study, the South is the eleven states that seceded from the Union and formed, albeit briefly, the Confederate States of America. These states are comprised of 1,143 different counties and, in Virginia, independent cities. Politically, the South has been marked by a history of one-party dominance associated with having a traditionalistic political culture (Elazar 1966). For most of the next century after the Civil War, Key noted that "the politics of the South revolves around the position of the Negro" $(1949,5)$ and much of the focus of southern politics revolved around racial politics. The landmark court case Brown v. Board of Education (1954), the enactment of the Civil Rights Act of 1964, and the Voting Rights Act of 1965 substantially changed the United States and especially the South. Despite these

CHAD J. KINSELLA is Assistant Professor of Political Science at Lander University, Greenwood, South Carolina.

The American Review of Politics, Vol. 34, Fall, 2013: 227-240

(C)2013 The American Review of Politics 
changes, along with a host of other social, economic, and demographic changes that constitute the "New South," race continues to be an important part of understanding southern politics (Glaser 1996; Kuklinski et al. 1997).

Until the 1980 s, the Democratic Party was the dominant party in the South, which was referred to as the "Solid South" because of its unwavering backing of that party. By the 1980s, if not earlier, the supremacy of the Democratic Party in the South was over (Black and Black 1987). Republicans began to make inroads into southern states, capturing most or all of the electoral votes in the states by the 1980 presidential election. In 1994, Republicans began to translate their presidential election success into congressional seat gains (Glaser 1996). Republicans have consolidated those gains and have become the dominant political party in most southern states (Bartels 2000). By the 2008 presidential election, after decades of Republican work and cultivation, from Nixon's to Reagan's respective southern strategies, the South was considered a major source of the necessary electoral votes for Republican presidential candidates.

Therefore, the 2008 presidential election represents a significant departure from politics as usual in several southern states. First, Virginia, one of the first southern states to vote reliably Republican in presidential elections since 1964, broke with tradition and voted for Obama. Also, North Carolina is beginning to solidify its credentials as a battleground state, taking its place with Virginia and Florida as the only such states in the South. Second, contrary to the political moves by Virginia and North Carolina toward the Democratic Party, other states in the Upper South, most notably Arkansas and Tennessee, continued to solidify their support for the Republican Party.

A key element to understanding what happened in the 2008 election, as with any election, is to examine the geography and analyze the contextual effects of the election. To that end, this analysis will explore the spatial variations, by county, of voting behavior in the South. First, an analysis of a phenomenon referred to as geographic "clustering" will be completed. "Clustering" is the idea first presented by Bill Bishop in his book The Big Sort that politically like-minded individuals cluster in geographic areas, in this case counties, with others politically and culturally like themselves (2008). This will be tested using "landslide" counties, or counties in which the vote for the Democrat or Republican candidate meets or exceeds a margin of a twenty percent victory (Bishop 2008) in order to visualize the pattern of voting within the region and further the idea that the "who" and "where" are often one in the same question.

Second, this study explores the spatial variation of the change in political support across the region. This is done by analyzing where political support for the Republican candidate, John McCain, in 2008 changed appreciably from support received by President Bush in 2004. Furthermore, using 
a host of demographic and economic variables, a contextual analysis will be made to explain party support in 2008 and vote change between 2004 and 2008.

The purpose of this study is to conduct an exploratory, descriptive analysis of the spatial variation of voting in the South and uncover the causes of what is observed. Although no hypothesis is tested, the analysis is important for several reasons. Primarily, this analysis will attempt to answer two key questions: who and where. This analysis will also show critical trends in voting across the South that have great importance for elections ranging from presidential to local.

The unit of analysis used to examine the 2008 presidential election results are counties and, in the case of Virginia, independent cities. County level voting results "are prime ingredients in the U.S. presidential election system, and an ecological analysis is therefore fully justified" (Lesthaeghe and Neidert 2009, 392). Not only will the voting patterns of the counties be analyzed but so will the demographic and economic characteristics of the residents of the southern counties in an effort to understand the contextual background behind county-level voting patterns.

Context is "a geographically bounded social unit" (Books and Prysby $1991,2)$, including such things as states, counties, cities, communities, precincts, voting districts, census tracts, and neighborhoods. In this case, we will focus on counties and independent cities exclusively. Contextual effects occur when some aspect of the community in which a person resides alters the flow and meaning of the information that the individual receives. This altered flow and interpretation may lead the individual to behave differently in this specific context than another. Ultimately, people in one context have access to different informational cues than people in other contexts. The goal of contextual theory is to advance social science theory and understanding by finding the extent of contextual effects and discovering the mechanisms by which environments influence individuals (Books and Prysby 1991).

\section{Methods}

Data for this analysis come from a variety of sources. First, demographic and economic data was collected from the Census Bureau for all counties and cities within the eleven states analyzed. This data enables a contextual analysis of variations of voting behavior that cannot be obtained from national or state-level surveys. The primary focus of the contextual analysis will be to identify factors that best explain the Democratic share of the vote in southern counties and cities as well as the change in vote between 2004 and 2008. Three statistical methods will be employed: correlation, regression and factor analysis. 
Second, election results for all counties in cities in the South were needed. To obtain this data, each state election repository within the study area was used to collect data for the 2004 and 2008 elections. A dataset of the election results for all eleven states was compiled and new variables were created from the original election data in order to analyze the results. In order to show spatial variations of election results, landslide counties were calculated using the following formula:

\section{(Republican Votes/Total Votes) - Democratic Votes/Total Votes}

This formula creates a score that ranges from 1 , if all votes were for the Republican candidate, to -1 , if all votes were for the Democratic candidate. A score of "0" would indicate that the precinct was split between the two parties, half voting Republican, half voting Democratic. These scores were used to determine whether a precinct was a "landslide" precinct or not and for which party.

The landslide methodology is borrowed from Bishop (2008), but the analysis diverges from Bishop's methodology in that third party candidates were left in the total number of votes. It is important to note that some third party candidates did not make the ballot in all eleven states in the study area, and write-in candidates vary from state to state. If a county received a score of 0.20 to 1.00 , the county was considered a Republican landslide. Likewise, if the county received a score of -0.20 to -1.00 , the county was considered a Democratic landslide. Finally, if a county had a score between more than -0.20 and less than 0.20 there was no landslide victory for either party. The results of this methodology are mapped in Figure 1.

To reveal counties that have changes in the presidential vote between 2008 and 2004 the following formula is used:

\section{Percent Republican 2008 - Percent Republican 2004}

The resulting number indicates whether there was an increase or decrease in the percent of the vote received by the Republican candidate between 2008 and 2004 and by what amount. Figure 2 maps counties by the degree to which election results changed between the two presidential elections. Lighter shaded counties indicate an increase in Republican voting and dark shaded counties indicating declines in Republican voting.

\section{Findings and Discussion}

Of the 1,143 counties and cities (Virginia only), 759 of them are considered landslides for either McCain or Obama, indicating a twenty percent 
Figure 1. 2008 Landslide Counties in the South

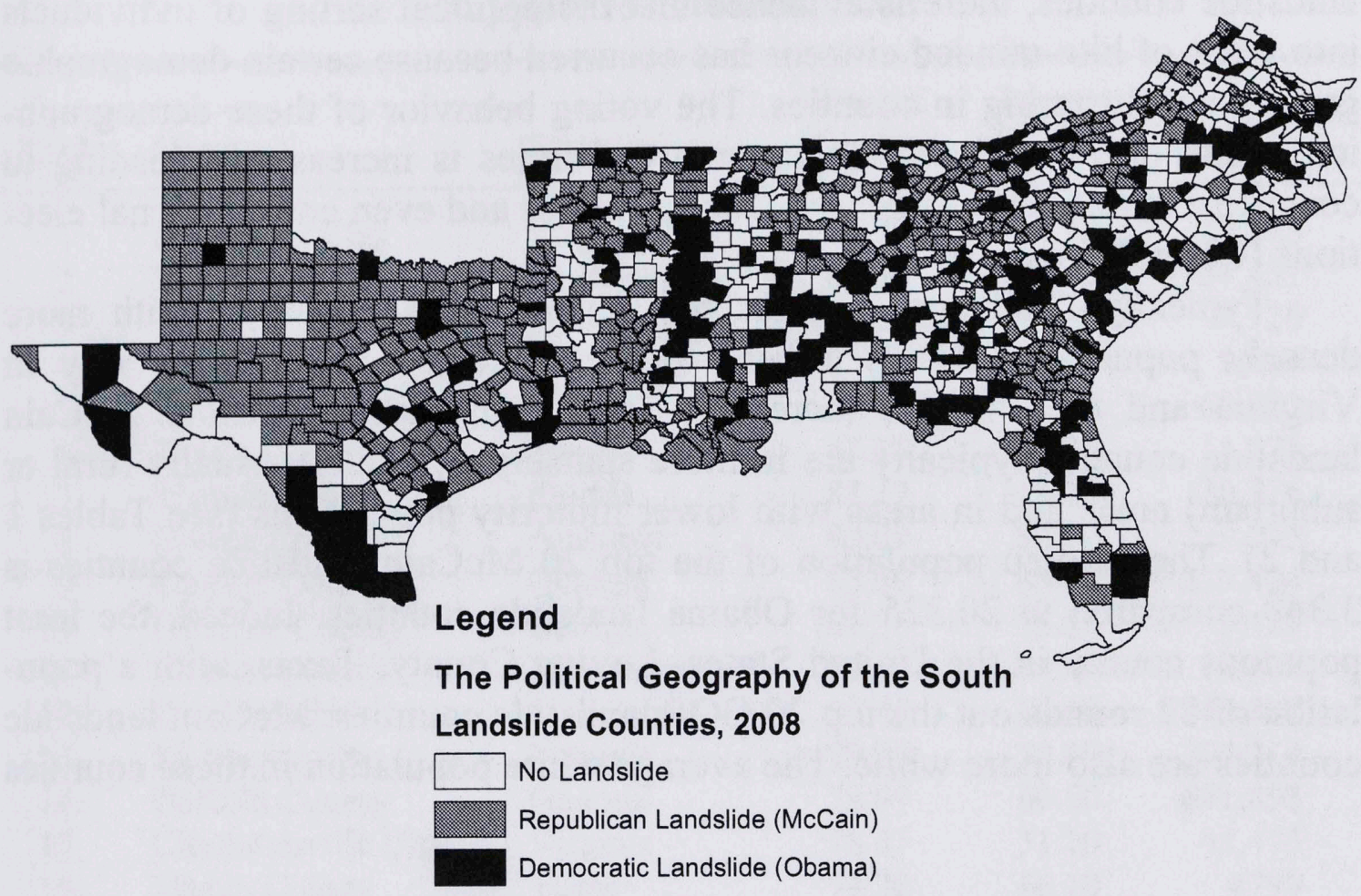

Figure 2. Difference in Republican Vote Share, 2004-2008

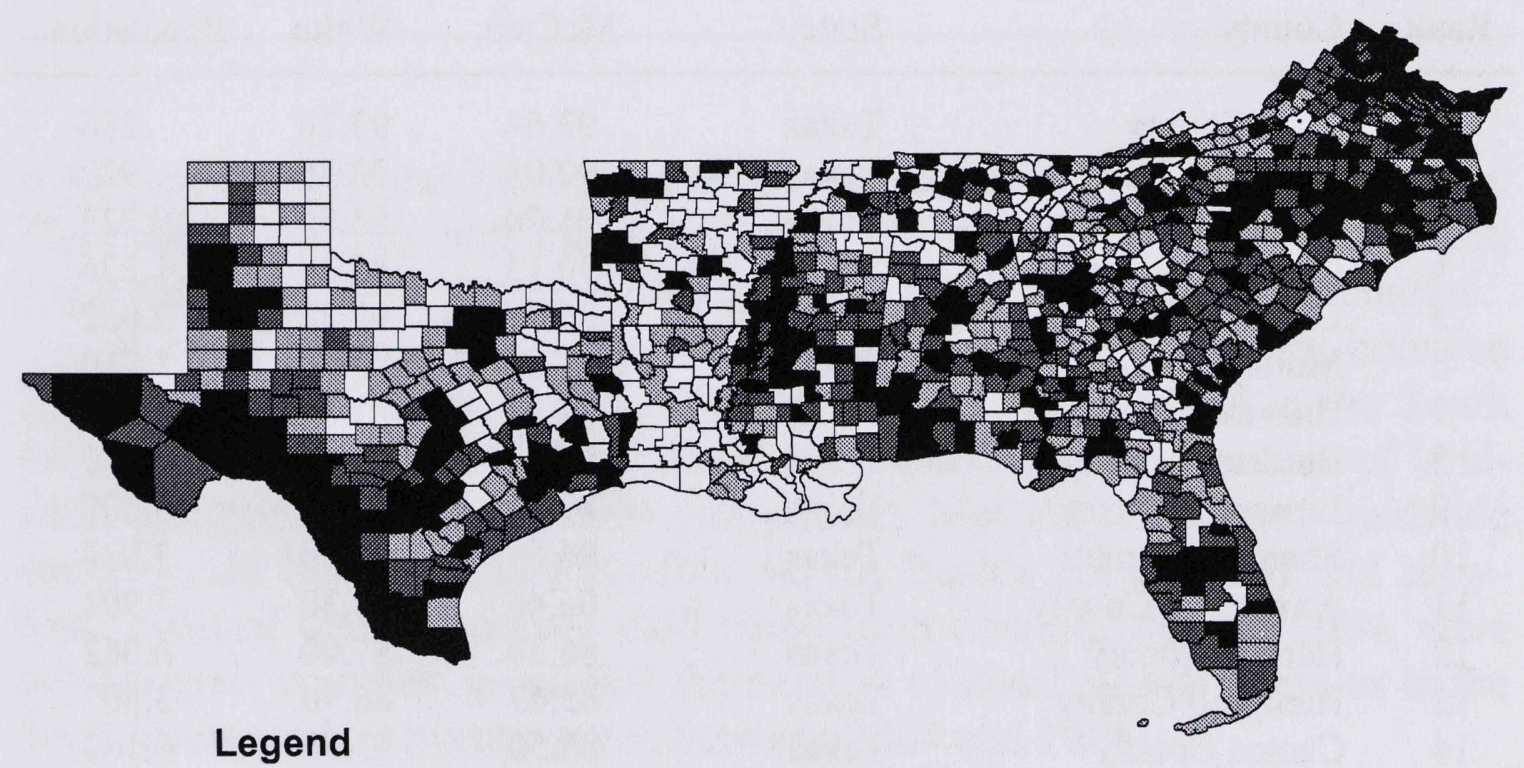

The Political Geography of the South

Difference in Republican Share of the Vote between 2004 and 2008 by Percent

$-18.94 \%--5.45 \%$
$-5.46 \%--2.91 \%$
$-2.91 \%-0.83 \%$
$0.84 \%-15.82 \%$


victory or more by either candidate (see Figure 1). Given the grouping of landslide counties, there is evidence that the political sorting of individuals into areas of like-minded citizens has occurred because certain demographic groups are clustering in counties. The voting behavior of these demographically and now politically homogenous counties is increasingly leading to consistent results in presidential (Bishop 2008) and even congressional elections (Oppenheimer 2005).

Typically, landslide counties for Obama are in counties with more densely populated (usually urban) areas including almost every city in Virginia and areas where there is a large minority population. McCain landslide counties typically are in more sparsely populated (usually rural or suburban) areas and in areas with lower minority populations (see Tables 1 and 2). The median population of the top 20 McCain landslide counties is 3,340 compared to 20,325 for Obama landslide counties. Indeed, the least populous county in the United States, Loving County, Texas, with a population of 82 rounds out the top $20 \mathrm{GOP}$ landslide counties. McCain landslide counties are also more white. The average white population in these counties

\section{Table 1. Southern Counties with Highest Percent Support for McCain, 2008}

\begin{tabular}{rllrrr}
\hline Rank & County & State & $\begin{array}{c}\text { Percent } \\
\text { McCain }\end{array}$ & $\begin{array}{r}\text { Percent } \\
\text { White }\end{array}$ & Population \\
\hline 1 & King County & Texas & 92.64 & 93.70 & 286 \\
2 & Roberts County & Texas & 92.08 & 93.80 & 929 \\
3 & Ochiltree County & Texas & 91.70 & 85.60 & 10,223 \\
4 & Glasscock County & Texas & 90.13 & 85.20 & 1,226 \\
5 & Oldham County & Texas & 88.37 & 90.20 & 2,052 \\
6 & Motley County & Texas & 87.88 & 92.10 & 1,210 \\
7 & Hansford County & Texas & 87.87 & 81.80 & 5,613 \\
8 & Borden County & Texas & 87.53 & 93.60 & 641 \\
9 & Lipscomb County & Texas & 87.02 & 86.20 & 3,302 \\
10 & Sherman County & Texas & 86.67 & 88.30 & 3,034 \\
11 & Armstrong County & Texas & 86.46 & 93.30 & 1,901 \\
12 & Hartley County & Texas & 86.20 & 87.00 & 6,062 \\
13 & Hemphill County & Texas & 85.67 & 86.90 & 3,807 \\
14 & Carson County & Texas & 85.50 & 93.90 & 6,182 \\
15 & La Salle Parish & Louisiana & 85.49 & 85.20 & 14,890 \\
16 & Wheeler County & Texas & 85.43 & 82.60 & 5,410 \\
17 & Shackelford County & Texas & 85.32 & 93.10 & 3,378 \\
18 & Gray County & Texas & 85.13 & 81.50 & 22,535 \\
19 & Livingston Parish & Louisiana & 85.02 & 91.90 & 128,026 \\
20 & Loving County & Texas & 84.81 & 79.30 & 82 \\
& & & & & \\
\hline
\end{tabular}




\section{Table 2. Southern Counties with Highest Percent Support for Obama, 2008}

\begin{tabular}{rllrrr}
\hline Rank & County & State & $\begin{array}{r}\text { Percent } \\
\text { Obama }\end{array}$ & $\begin{array}{r}\text { Percent } \\
\text { Minority }\end{array}$ & Population \\
\hline \multirow{2}{*}{1} & Petersburg City & Virginia & 88.64 & 84.10 & 32,420 \\
2 & Macon County & Alabama & 86.88 & 84.20 & 21,452 \\
3 & Jefferson County & Mississippi & 86.71 & 86.30 & 7,726 \\
4 & Claiborne County & Mississippi & 85.86 & 85.70 & 9,604 \\
5 & Starr County & Texas & 84.50 & 96.10 & 60,968 \\
6 & Zavala County & Texas & 84.18 & 95.20 & 11,677 \\
7 & Wakulla County & Florida & 83.17 & 19.10 & 30,776 \\
8 & Greene County & Alabama & 83.09 & 82.70 & 9,045 \\
9 & Clayton County & Georgia & 82.99 & 85.30 & 259,424 \\
10 & Hancock County & Georgia & 81.38 & 76.50 & 9,429 \\
11 & Holmes County & Mississippi & 81.37 & 84.40 & 19,198 \\
12 & Orleans Parish & Louisiana & 79.42 & 68.60 & 343,829 \\
13 & Richmond city & Virginia & 79.09 & 59.60 & 204,214 \\
14 & DeKalb County & Georgia & 78.99 & 69.60 & 691,893 \\
15 & Charlottesville City & Virginia & 78.35 & 31.20 & 43,475 \\
16 & Martin County & Texas & 78.20 & 46.10 & 4799 \\
17 & Noxubee County & Mississippi & 76.34 & 72.80 & 11,545 \\
18 & Tunica County & Mississippi & 75.69 & 76.60 & 10,778 \\
19 & Brooks County & Texas & 75.66 & 92.30 & 7,223 \\
20 & Durham County & North Carolina & 75.57 & 56.70 & 267,587 \\
& & & & & \\
\hline & & & & & \\
\hline
\end{tabular}

is 88 percent, whereas Obama landslide counties are 73 percent non-white. The median minority population in these pro-Obama counties is 80 percent, suggesting there were some outliers among these Obama landslide counties.

It is also important to note the change in landslide counties between 2004 and 2008. Obama picked up forty-six landslide counties in the South for a total of one hundred and fifteen, almost doubling the number of landslide counties Kerry had in 2004 (sixty-nine). McCain lost twenty landslide counties; six hundred and forty-four versus Bush's six hundred and sixtyfour. Most of the Democratic shift came from counties that, in 2004, were not landslide counties, given that the number of non-landside counties in the South decreased by twenty-seven between 2004 and 2008.

Second, Figure 2 suggests that there are some key spatial patterns. Several states, especially Virginia and North Carolina have large clusters of counties that had significant vote losses for the Republican Party in 2008 compared to the 2004 Presidential Election. It is also important to note that in several states McCain won in 2008 such as Mississippi, Georgia, Alabama, and Texas there are large clusters of counties in which the number of 
people who voted for President Bush four short years ago either did not show up or voted for Obama in 2008, decreasing the Republican margin of victory in those states. This trend in southern counties matches much of what happened nationally (Deskins et al. 2010).

Perhaps the only bright spots for the GOP on the map in 2008 are in the Upper South, such as Tennessee and Arkansas, as well as portions of Texas and Louisiana. In Tennessee, there are a large number of counties in the western and central areas of the state where the Republican share of the vote increased from 2004 to 2008. Likewise, many counties in Arkansas registered a substantial increase in support for the Republican ticket from 2004 to 2008. Finally, almost every parish in Louisiana increased the percent of votes given to the Republican candidate in 2008 from 2004.

Now that we know "where," the next question is "who?" The Census Bureau collects large amounts of data that is aggregated to counties. Although political scientists typically rely on survey data to tell us about the relationship between demographics and political behavior, there is a wealth of county-level hard data. The Census Bureau also collects information typically missing in survey research that allows for expanded analysis and, given that this covers a specific region, data from the eleven states may be compiled and analyzed from the same dataset allowing for a large number of observations not typically available in survey research. The methods employed in this study closely mirror the contextual analysis completed by Brown et al. (2005) in their study of an initiative to repeal a gay rights ordinance in Tacoma, Washington. Despite the significant differences between their study and this analysis, their methods offer a solid foundation for completing a contextual analysis that unites voting and Census data.

In order to determine which variables in this contextual analysis offer some explanation of the Democratic share of the presidential vote in the South in 2008 and the change in the Republican share of the vote between 2004 and 2008, a correlation matrix of politically relevant variables was created (see Table 3 ). According to the correlation matrix, those variables most strongly and positively correlated to the Democratic vote in 2008 were the presence of sizable black populations, younger populations (20-34), populations with higher levels of education, higher percentages of unemployed and impoverished, and higher proportions of government employees within a county. Variables strongly and positively correlated with an increase in Republican vote share between 2004 and 2008 include substantial numbers of whites, older populations, married couples, and counties with a large number of people who are self-employed. An interesting finding is that a county's Hispanic population has a negative and significant correlation to the difference in GOP vote share between 2004 and 2008, but has no significant correlation to the percent voting Democratic in 2008. 
Table 3. Correlation of Vote to Demographic Variables

\begin{tabular}{|c|c|c|}
\hline Variable & $\begin{array}{l}\text { Percent Voting } \\
\text { Obama, } 2008\end{array}$ & $\begin{array}{c}\text { Percent Change, } \\
\text { 2004-2008 }\end{array}$ \\
\hline$\%$ Male & -.123 & .033 \\
\hline$\%$ White & -.476 & .227 \\
\hline$\%$ Black & .469 & -.145 \\
\hline$\%$ Hispanic & .000 & -.265 \\
\hline$\%$ with Less than HS & -.033 & .036 \\
\hline$\%$ HS Only & -.144 & .112 \\
\hline$\%$ Some College & .093 & -.066 \\
\hline$\%$ Bachelors & .158 & -.167 \\
\hline$\%$ Graduate & .176 & -.205 \\
\hline Per Capita Income & -.060 & -.115 \\
\hline$\% 18$ and under & -.025 & -.114 \\
\hline$\% 19$ to 34 & .231 & -.187 \\
\hline$\% 35$ to 49 & -.046 & -.002 \\
\hline$\% 50$ to 64 & -.092 & .180 \\
\hline$\% 65$ and Above & -.129 & .168 \\
\hline Id, $(p<$ & & \\
\hline
\end{tabular}

Many of these findings echo national public opinion and exit polls conducted after the 2008 election. Gallup's exit polling found that McCain did best among whites, seniors, men, churchgoers, and Protestants. In contrast, Obama did well with minorities, non-churchgoers, younger voters, and those with a post-graduate education. Furthermore, the exit poll found that age groups between 30-49 and 50-64 substantially increased their vote for the Democratic candidate between 2004 and 2008, as did those with some college and a college degree, and all minorities, especially Hispanics (Saad 2008).

In order to further assess the strength of demographic and economic variables associated with voting for McCain and change in the county-level vote between 2004 and 2008 a regression analysis was performed. Table 4 shows the OLS regression results with the dependent variable being percent of the county voting for the Republican presidential candidate. All independent variables are measured as percentages with the exception of per capita income, which is in thousands of dollars. The 2004 county vote percentage for McCain is included to control for normal GOP strength in the county. Aside from the 2004 GOP vote percentage, a county's Hispanic and black population percentages had a significant $(\mathrm{p}<.001)$ and negative effect on support for McCain. More youthful counties were less likely to support the Republican candidate, as were counties with older populations, though the 
Table 4. Regression on Percent Voting for McCain in 2008

\begin{tabular}{|c|c|c|}
\hline Variable & Coefficient & Standard Error \\
\hline$\%$ White & .060 & .039 \\
\hline$\%$ Black & $-.186 * * *$ & .041 \\
\hline$\%$ Hispanic & $-.240 * * *$ & .014 \\
\hline$\%$ Female & $-.683 * * *$ & .088 \\
\hline Per Capita Income & $-.190 * * *$ & .040 \\
\hline \% Less than High School Degree & $.110^{*}$ & .051 \\
\hline \% High School Degree & $.097^{\#}$ & .050 \\
\hline$\%$ Some College & .062 & .051 \\
\hline$\% 20$ to 34 & $-.846 * * *$ & .099 \\
\hline$\% 35$ to 49 & $-.980 * * *$ & .139 \\
\hline$\% 50$ to 64 & $-.532 * * *$ & .117 \\
\hline$\% 65$ and Above & $-.562 * * *$ & .083 \\
\hline \% Voting Republican, 2004 & $.823 * * *$ & .015 \\
\hline Constant & $95.602 * * *$ & 12.503 \\
\hline Adjusted $\mathrm{R}^{2}$ & .894 & \\
\hline $\mathrm{N}$ of Cases & 1140 & \\
\hline \multicolumn{3}{|c|}{$* * * * p<.001 ; * * * p<.01$ level; $* * p<.05 ;{ }^{*} p<.10$} \\
\hline
\end{tabular}

coefficients for the two older age cohorts are considerably smaller. Differences in county-level education mattered somewhat, with counties with higher high school graduate rates and counties with relatively more students with less than a high school diploma contributing to GOP gains. (The omitted variable is the percent of a county's population with a bachelor's degree or higher.) Evidence of a gender gap in southern counties is also found. Holding all other variables constant at their mean value, a one percent increase in the county female population translated into a .683 percentage decline in McCain's vote percentage. Interestingly, per capita income is negative and statistically significant $(\mathrm{p}<.001)$. This means that more affluent counties delivered more votes to Obama than McCain; a problem highlighted in Howard Dean's now-famous lament regarding low-income southern voters' preoccupation with, "God, Gays, and Guns." With an adjusted r-square of .894, the model does a good job of explaining GOP presidential vote percentages in southern counties.

Table 5 reports coefficient estimates predicting the change in the percent voting Republican between 2004 and 2008. Higher values for the dependent variable indicate that the vote for McCain was more than the Republican vote for G.W. Bush in 2004. With the exception of the 2004 Republican county vote percentage, the independent variables in the vote change model are the same as those reported in Table 4 . The coefficients, by and large, are 
Table 5. Regression on Percent Republican Vote Change, 2004-2008

\begin{tabular}{lcc}
\hline Variable & Coefficient & Standard Error \\
\hline \% White & $.072^{\#}$ & .040 \\
$\%$ Black & -.032 & .040 \\
$\%$ Hispanic & $-.151^{* * *}$ & .014 \\
\% Female & $-.344^{* * *}$ & .086 \\
Per Capita Income & $-.120^{* *}$ & .040 \\
$\%$ Less than High School Degree & .062 & .052 \\
$\%$ High School Degree & .027 & .051 \\
$\%$ Some College & .026 & .051 \\
$\%$ 20 to 34 & $-.466^{* * *}$ & .095 \\
$\% 35$ to 49 & $-.663^{* * *}$ & .137 \\
$\% 50$ to 64 & $-.220^{\#}$ & .116 \\
$\% 65$ and Above & $-.352^{* * *}$ & .082 \\
Constant & $43.788^{* * *}$ & 12.110 \\
Adjusted $\mathrm{R}^{2}$ & 0.219 & \\
N of Cases & 1140 & \\
$* * * * p<.001 ; * * * p<.01$ level; ${ }^{* *} \mathrm{p}<.05 ;{ }^{*} \mathrm{p}<.10$ & \\
\hline
\end{tabular}

similar in effect and level of statistical significance to that of the GOP vote share model. There are, however, some important differences. A county's black population is no longer statistically significant $(p=.433)$. Thus, counties with larger black populations certainly aided in Obama's vote totals, but after accounting for other relevant variables larger black populations were not significantly more important in 2008 versus 2004 . On the other hand, the effect of more white counties on the change in GOP vote percentages between the two elections is now marginally significant $(p=.074)$. One last difference between the two models is the effect of education. Counties with relatively more lower educated residents did not significantly change their vote patterns from 2004 to 2008 . The coefficients for these variables are positive, as they were in the Republican vote share model, but fall short of conventional levels of statistical significance.

Before concluding, it is critical to mention a couple of important methodological considerations when considering the contextual analysis completed here. As discussed by noted political scientist Gary King, when conducting a contextual analysis with geographic units as vast as counties there is a possibility of committing ecological fallacy (King 1997). In the United States, it is not required that all eligible voters actually vote, therefore when analyzing the county vote compared to county populations there is an inherent risk of drawing too strong of a conclusion from the contextual results provided. 
It is possible that there is a strong link between voting behavior in a county and percent unemployed, for example. However, if a county has a turnout of only forty percent it is possible that few, if any, unemployed people actually voted. This does not make contextual analysis mute, as King once suggested (King 1996), but it does indicate that some care should be taken when interpreting the results.

Second, it is important to note the maps presented in this analysis are not weighted by population. Although the mapping methodology employed here does show voting patterns it does not account for the population and total number of votes delivered out of each county. As noted by Gimpel and Schuknect (2002) in their analysis of state regional voting behavior, even urban counties that may vote overwhelmingly Democratic in terms of percentages may still deliver a large number of votes to the GOP candidate relative to sparsely populated rural counties that provide overwhelming support to the GOP but fewer actual votes.

\section{Conclusions and Future Research}

The politics of the South is critical to the understanding of American politics (Key 1949). The eleven states that make up the South, as of 2008, have 153 of the 270 electoral votes necessary to become president (Buchanan 2009). However, after the 2010 Census, several southern states have picked up even more electoral votes because of their growth over the last decade. The results of the 2010 Census would normally be a reason for Republicans to celebrate. For the last several decades the eleven states that make up the South have been a critical part of the Republican electoral coalition, which also includes states in the West. Those western and southern states have been reliably Republican - until recently.

Not all of the news is bad for Republicans, however. States in the "Rim South" such as Arkansas and Tennessee have deepened their commitments to the GOP. Also, Louisiana strengthened its claim as a "Red State" in the 2008 presidential election. Outside of Florida, every southern state to obtain more electoral votes in 2012 also remained in the Republican camp in 2008, which was arguably one of the worst years in a long time for the Republican Party nationally and in the South (Buchanan 2009).

What does the political future hold for the South, given the results of the 2008 election? As this article is being written, the 2012 presidential race is underway. Currently, Virginia, North Carolina, and Florida remain "battleground" states. They remain must-win states for the Republicans but not for the Democrats. Without a united front, there are some indications that the South, once a key region in presidential elections, has become less important and marginalized itself (Nossiter 2008). Increasingly, the formula 
for success for Democratic presidential candidates is to create a strategy that ignores and simply goes around the southern states, making them marginal players in the big game of presidential elections (Schaller 2006).

Another key conclusion from this contextual analysis: race still matters in the South. Whites in the South voted more disproportionately against Obama than whites in other states, with eight of eleven southern states joining five other states to offer the lowest amount of white votes to Obama in the nation (Clayton 2010). Furthermore, blacks in the South also show no interest in breaking with their long held voting patterns. Therefore, despite both presidential candidates eschewing racial politics in 2008 (SinclairChapman and Price 2008; Clayton 2010), many in the South still see politics through a racial lens.

While much analysis of southern politics relies mainly on data from surveys, this study suggests there may be an opening for an increased use of geographic or contextual analysis. When analyzing specific regions or even specific states, there may be richer datasets available via the Census Bureau to explore demographic and economic variables and their effect on voting. National surveys and exit surveys typically have fewer variables and smaller samples to analyze regional and state vote patterns and behavior. There are many other variables to explore and almost unlimited opportunity to manipulate the Census Data for further, more detailed observations in future studies.

\section{REFERENCES}

Bartels, Larry M. 2000. Partisanship and Voting Behavior, 1952-1996. American Journal of Political Science 44:35-50.

Bishop, Bill. 2008. The Big Sort: Why the Clustering of Like-Minded America is Tearing Us Apart. New York: Houghton Mifflin Company.

Black, Earl, and Merle Black. 1987. Politics and Society in the South. Cambridge, MA: Harvard University Press.

Books, John W., and Charles L. Prysby. 1991. Political Behavior and the Local Context. New York: Praeger.

Brown, Michael, Larry Knopp, and Richard Morrill. 2005. The Culture Wars and Urban Electoral Politics: Sexuality, Race, and Class in Tacoma, Washington. Political Geography 24:267-291.

Buchanan, Scott E. 2009. The Continued Convergence of Demographics and Issues. Pp. 3-16 in A Paler Shade of Red: The 2008 Presidential Election in the South, eds. Branwell Kapeluck, Laurence Moreland, and Robert Steed. Fayetteville: University of Arkansas Press.

Clayton, Dewey M. 2010. The Presidential Campaign of Barack Obama: A Critical Analysis of a Racially Transcendent Strategy. New York: Routledge. 
Deskins, Donald R., Hanes Walton, Jr., and Serman C. Puckett. 2010. Presidential Elections, 1789-2008: County, State, and National Mapping of Election Data. Ann Arbor: University of Michigan Press.

Elazar, Daniel. 1966. American Federalism: A View from the States. New York: Crowell.

Gimpel, James G., and Jason E. Schuknecht. 2002. Reconsidering Political Regionalism in the American States. State Politics and Policy Quarterly 2(4):325-352.

Glaser, James M. 1996. Race, Campaign Politics, and the Realignment in the South. New Haven, CT: Yale University Press.

Key, V.O., Jr. 1949. Southern Politics in State and Nation. New York: Alfred A. Knopf.

King, Gary. 1996. Why Context Should Not Count. Political Geography 15(2):159-164.

King, Gary. 1997. A Solution to the Ecological Inference Problem. Princeton, NJ: Princeton University Press.

Kuklinski, James H., Michael D. Cobb, and Martin Gilens. 1997. Racial Attitudes and the 'New South.' Journal of Politics 59:323-349.

Lesthaeghe, Ron, and Lisa Neidert. 2009. U.S. Presidential Elections and the Spatial Pattern of the American Second Demographic Transition. Population and Development Review 35:391-400.

Nossiter, Adam. 2008. For South, A Waning Hold on National Politics. Posted on New York Times website, http://www.nytimes.com/2008/11/11/us/politics/11south.html? pagewanted=all\&_moc.semityn.www, accessed October 23, 2011.

Oppenheimer, Bruce. 2005. Deep Red and Blue Congressional Districts: The Causes and Consequences of Declining Party Competitiveness. Pp. 135-158 in Congress Reconsidered, 8th ed., eds. Lawrence Dodd and Bruce Oppenheimer. Washington, DC: Congressional Quarterly Press.

Saad, Lydia. 2008. Blacks, Postgrads, Young Adults Help Obama Prevail. Posted on Gallup website, www.gallup.com, accessed November 6, 2008.

Schaller, Thomas. 2006. Whistling Past Dixie: How Democrats Can Win Without the South. New York: Simon and Schuster.

Sinclair-Chapman, Valeria, and Melanye Price 2008. Black Politics, the 2008 Election, and the (Im)possibility of Race Transcendence. PS: Political Science and Politics 41:739-745.

U.S. Bureau of the Census. n.d. American FactFinder. Available at http://factfinder2. census.gov/faces/nav/jsf/pages/index.xhtml. 